\title{
Elements of Critical Discourse in Copywriting on Malaysian Celebrity Television Advertisement
}

\author{
Nur Widad Roslan ${ }^{1}$, Hazlina Abdul Halim${ }^{1}$, Mohd Azidan Abdul Jabbar ${ }^{1} \&$ Roslina Mamat $^{1}$ \\ ${ }^{1}$ Faculty of Modern Languages and Communication, University Putra Malaysia, Serdang, Malaysia \\ Correspondence: Hazlina Abdul Halim, Faculty of Modern Languages and Communication, Universiti Putra \\ Malaysia, Serdang, 43400 Selangor, Malaysia. Tel: 6-010-299-3064.E-mail: hazlina_ah@upm.edu.my
}

Received: August 30, 2018

Accepted: January 4, 2019 Online Published: January 30, 2019

doi:10.5539/ass.v15n2p17

URL: https://doi.org/10.5539/ass.v15n2p17

\begin{abstract}
This study focuses on the elements of critical discourse in copywriting on Malaysian celebrity television advertisements. The objectives of this study is to identify and discuss the elements of critical discourse in copywriting on Malaysian celebrity television advertisement videos. This study will focus on the textual analysis, one of the three dimensions of Fairclough's (1995) critical discourse analysis. The data is analyzed by using the qualitative method. 10 Malaysian celebrity television advertisements copy were chosen as samples for this study. Results from this study have helped in the process of identifying the presence of the textual analysis sub categories which are grammar, theme, metaphor, repetition and conjunction. Therefore, it is hoped that further studies will be focus on the use of appropriate textual analysis in future advertisement copies.
\end{abstract}

Keywords: discourse, copy, television advertisement, textual analysis, Malaysian, critical discourse

\section{Introduction}

As mentioned in the Economic Times (2017), advertising is a communication method to consumers of a product or service. Advertising is also a paid method by a brand to inform or influence customers and potential customers about their products or services. Advertising has been around for a long time, but not many are aware of it. In the olden days, advertising used mediums such as television, print (newspapers, magazines, journals etc.), radio and many more. That is why, recently the olden days advertising is named as the traditional advertising, while the present advertising which is more to using the digital era, contests, sponsorship, events, endorsements and many more (Karimova, 2011), is named the name digital advertising.

In any advertisement, there is a copywriter involved. Copywriters are the content providers for advertisement for both broadcast and print which includes tag lines and slogans, brochures, website, leaflets, direct mail, articles, marketing mails, users guide, video scripts and many more (Petri, 2012; Bergkvist, Hjalmarson, \& Magi, 2016). Petri (2012) remarked that a copywriter is a reference to someone and who creates concept and content for the advertisement they are working on. In other words, a copywriter is a person who writes the word, phrase, sentence structure that create a meaningful and persuasive towards readers or listeners thus, it is an art of copywriting that manages to arouse interest.

The objectives of this study is to identify and discuss the elements of textual analysis in the copywriting on Malaysian celebrity television advertisements by applying Fairclough's (1995) framework study will focus on the textual analysis, one of the three dimensions of critical discourse analysis.

Discourse analysis of spoken and written language, proved to be very helpful and inspiring in linguistics studies (Stubbs, 1983; Brown \& Yule, 1983; van Dijk, 2008; Biber \& Gray, 2013). The studies will help the process of understanding and comprehensibility of the language. In this study, the job of copywriters will be explained and understood. The copywriters will prepare the text after thorough discussion with the team members in the advertising company. The text will then be given to the celebrity chosen for the endorsement in television advertisements. The celebrity will ensure that the copywriting will be uttered or spoken in the advertisement.

The copywriting on the other hand, will be focused on the language structure in order for the messages to be comprehensible and attractive to the consumers. The language written focused not only the grammatical and lexical cohesion, clausal relations and text patterns but should also be dealing with written discourse analysis. The clausal relations as stated above, include logical sequence, matching or multiple clause relations, are defined 
as shared cognitive processes, whereby "we interpret the meaning of a clause or group of clauses in the light of their adjoining clause or group of clauses" (Winter, 1994, p. 49).

Biber and Gray (2013) claimed that the text patterns on the other hand, are something to show the writer's logic in organizing ideas and his/her actual way of presenting them in a written text. This is supported by Coulthard (1994, p. 7):

"Every writer is face with the problem of how or organize and present his/her non-linear message in comprehensible linear form."

The written text conforms to rule which are unconsciously followed by most successful writers on what native readers unconsciously expect to find (Biber \& Gray, 2013). By studying the textual and lexical elements of these texts, a person can learn to regularly recognize the overall structure of a text. In fact, McCarthy (1993, p. 31) goes as far as to say that, while the sequence of these structures may vary, a person should always find all the elements in a well-formed text. A good text will consist of linguistic features and grammatical rules in order to avoid confusion (Rahim, Affendi, \& Pawi, 2017; Biber \& Gray, 2013; van Dijk, 2008; Johnstone, 2007; Schiffrin, 1994). Coulthard (1994) added that the text can also be analyzed appropriately by using the written discourse in order to have better understanding.

Gee and Handford (2013) highlighted the importance of discourse analysis and how it plays an important role to making this world more meaningful through both spoken and written discourse. Written discourse is more related to text, where it involves cohesion and coherence to which are pivotal, therefore (Todirascu et al., 2013) stated that a sentence is more well understood when a sequence of a sentence is more coherent.

Halliday and Hasan (1976) stated that there are five cohesive devices which focus on grammar, which are reference, substitution, ellipsis, conjunction and lexical cohesion. Reference occurs when a subject is referred for an interpretation of what the reader wants the message to be represented, while substitution is when a word or phrase is substituted by another nominal, verbal or clausal to represent the original word or phrase (Halliday \& Hasan, 1976). Ellipsis, on the other hand materializes when a certain element is omitted in the text or speech with an assumption that the message will still be understood by the listener or reader (Halliday \& Hasan, 1976). The fourth device which is conjunction is normally used to connect ideas and clauses in a sentence. Lastly lexical cohesion, according to Halliday and Hasan (1976) involves the choice of vocabulary.

Halliday and Hasan (1976) further divided lexical cohesion into two categories, which are reiteration, which is a repetition of a lexical item and the other is collocation, where vocabulary items are associated and tend to co-occur as it is not bound to any single text.

Bartsch (1997) highlighted 5 factors of variation between speech and writing (spoken or written discourse), to which are paralinguistic signals as mentioned by Bartsch (1997), where the written language depends on description and punctuation in order to deliver the same signals. Other than that is preciseness, where oral materials or normally less precise as compared to written text, this is because written text are more beneficial as there are more words of choice and that writers spend more time researching and thinking of the right words to be used in the text, hence the preciseness is higher that oral.

Organizational is another factor of variation between speech and written discourse. Organizational is where the written style is carefully planned to be more concise, more information and more organized (Chafe, 1992). Another variation is deviations from default/unmarked orders, where this it is mostly used for oral materials and less used for written texts. Lastly, frequency of repetition to which as mentioned by Bartsch (1997), for oral materials, an item can be repeated to 4-5 times, but different as compared to written text where it will only be written once. Although Bartsch (1997) had highlighted 5 factors of variation between speech and text, Paltridge (2006) differentiated spoken and written discourse into 8 important aspects, to which the first one being grammatical intricacy that according to Halliday (1989) spoken and written from of grammatical intricacy had no big difference between the two as each has their own complexities.

In Fairclough's (1995) critical language study of language and power, he mentioned that the study is a combination of linguistics in discourse that relates to action and convention in a text. He also added any discourse and practice are the conventional types of discourse (Fairclough, 1989). The social order according to Fairclough (1989), is a structure of a social space of various domains and are easily associated with various practices, for example, practice on economic, education and politics.

Overall, this study involves critical discourse that is used in television advertisements (the copy). In advertising terms, it is called the copywriting within the advertisement. This study relates well to Fairclough (1995) the textual and social practice analysis, where the copy of the television advertisement, is the message that the 
brands try to deliver to consumers and has to be well written for them to understand.

A study by Constanzo and Goodnight (2008) showed that a celebrity endorses a brand help consumers recalling the brand. Their study focused on the use of celebrity endorser and the matching between the endorser and the endorsed brand. The study also focused on the copywriter's task in preparing the narrative spoken by the celebrity. The results of the study revealed that the celebrity could promote the brand successfully due to the influential of the professional athlete towards the country. This study is parallel to the study of Kim (2007) and Basil and Herr (2006) where the influence of copywriting in celebrity endorsement will help in the process of recalling the brand in the advertising world.

On the other hand, studies on celebrity endorsement, such as by Halonen-Knight and Hurmerinta (2010) showed the meanings of transfer in celebrity endorsement. Here it can be seen that the importance of both product and the celebrity in the order to have an increasing of market value. Fleck, Korchia and Le Roy (2012) agreed with Halonen-Knight and Hurmerinta (2010) and claimed that the choice made by customer to buy the product would be entirely on the success of the celebrity advertisement. Here, it can be seen the celebrity chosen plays an important role in giving awareness towards the product to the customers.

Consequently, studies on copywriters continue due to the importance of copywriters work in the advertising world. A study by Um and Lee (2015) looked at Korean advertising practitioner's perspectives on celebrity endorsement in the advertising world. At present, practitioner's perspectives have been ignored (Um \& Lee, 2015). Copywriters are involved in a way where they will provide valuable information in the advertisements. Due to the involvement of celebrities, the copywriters will ensure that the preparation suited the celebrities. The study also compared the perspective between advertising practitioners from their counterparts on the client side and the insights into the perspective roles in advertising campaigns. The results of the study revealed that Korean advertising considered the celebrity's likeability when selecting a celebrity endorser. Also, the most important criterion would be working with the copywriter's views towards the brand which involved the suitability and relevancy of the chosen celebrity.

The work of copywriter and the celebrity endorsement helped to generate awareness of the brand (Advertising Yearbook, 2011; Choi, Lee, \& Kim, 2005; Edwards \& La Ferle, 2009; Kim, 2007). On the other hand, Um and Lee (2015) agreed with Constanzo and Goodnight (2008) where copywriting played a major role in preparing advertisement which involved the chosen celebrity for a specific brand. However, Um and Lee (2015) disagreed with McCutcheon, Ashe, Houran and Maltby (2003) statement on the celebrity chosen is more important than the copywriting prepared. Um and Lee (2015) claimed that both played a similar important role in promoting a brand. Therefore, both parties will work hand in hand to ensure consumers looked at the brand.

Celebrity endorsement seemed to be of importance towards increasing the demand of product and market values. However, it seemed that the studies discussed have showed that the quality of copywriter writing will therefore influenced the values or quality of the advertisement which also involved the famous celebrity.

\section{Method}

This study uses qualitative method, where the researchers analyzed video recordings of television advertisements involving Malaysian celebrities. Ten Malaysian television advertisement copies were analyzed by using Fairclough's (1995) textual analysis (see Figure 1 below). These advertisements will be recorded and transcribed to analyse their content. The categories chosen in this research are cosmetics advertisements, food and beverages advertisements, electronics and telecommunication advertisements and personal, oral and home care advertisement due to the frequencies they appear in television.

Critical Discourse Analysis (Fairclough, 1995)

Critical Discourse Analysis (Fairclough, 1995)

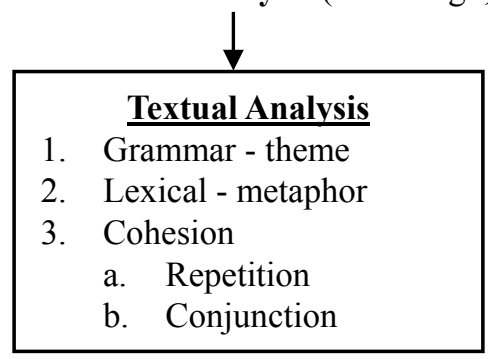

Figure 1. Theoretical Framework (Fairclough, 1995) 


\section{Results}

Below are the results based from the analysis of Fairclough (1995) textual analysis for Malaysian television advertisement copies.

\subsection{Vocabulary}

Vocabulary is where it is a list of words that is used and allowed by a certain language, group, individual, work or in their field of knowledge (Merriam-Webster Dictionary). It is found that in this study, the vocabulary used are mainly simply for easy understanding for consumers.

Table 1 below shows the example of the vocabulary use in two of the samples. It was found that in $\mathrm{C}$, the copywriter used a very simple vocabulary and easy to understand. This can be seen in the first line itself, "Life is a journey of discovery", the copy uses very simple and direct vocabulary to attract consumers. The second line of the advertisement explains further of the "discovery" where by the copy explains that "Take on challenges, and be inspired by his creation. Explore natures best." After the explanation of what the copy meant by "journey", the advertisement copy introduces the product along with the benefits of the product with direct explanation of vocabulary and highlighting the products advantages "Safi men facial cleanser, cooling sensation of $\mathrm{H} 2 \mathrm{O}$ cool cactus. "Deep cleansing. Oil Control. Experience true freshness. Safi Men. Discover your inner strength". Based on the vocabulary used in the advertisement, consumers can easily understand since the copy is very straight forward.

Table 1. Vocabulary

C1 Product: Safi Men

Celebrity Endorser: Fattah Amin

Copy: Life is a journey of discovery. Take on challenges, and be inspired by his creation. Explore nature's best, Safi men facial cleanser, cooling sensation of $\mathrm{H} 2 \mathrm{O}$ cool cactus. Deep cleansing. Oil Control. Experience true freshness. Safi Men. Discover your inner strength.

C2 Product: Lancome Love your Age

Celebrity Endorser: Neelofa

Copy: What stands out for me is having my own business at this age. Seeing it from to what it is today is just wonderful. I know I'm going to be 30 soon, but that won't stop me from pursuing what I want in life. Opportunities are everywhere, if you know where to find them. If you push yourself, you can inspire people and be happy, and achieve anything you want. At any age. The more I live, the younger I am. It's time to love your age.

On the other hand, the example shown in $\mathrm{C} 2$ used vocabulary which is more complex but can still be understood by consumers. From the copy itself, it can be seen that the advertisement focused more on story telling where the celebrity endorser was talking about herself and her ways to achieve anything while still being herself. The copy used words such as "If you push yourself, you can inspire people and be happy, and achieve anything you want" to inspire others to follow their dreams but at the same time not to forget about themselves.

The phrases used in the advertisement such as "If you push yourself, you can inspire people and be happy" helps to influence consumers. This is because the words used in the advertisement plays a big role in influencing consumers, especially trying to convince to making the consumers own decision. In this advertisement, simple copy were not an option as the main objective of the advertisement is to inspire the readers, hence if simple and less understood words are used in an advertisement to persuade consumers, it will not succeed. This is because consumers would think that the advertisement is just trying to be humorous and simply getting consumers to buy product, while the advertisement in $\mathrm{C} 2$ uses intricate vocabulary to capture the consumers' attention.

\subsection{Theme}

According to Fulcher (2010), in the discourse of texts, the theme refers to those that relate to a certain identity such as statements of a certain view. Overall in this study, it was found the presence of theme are often seen in the beginning of advertisements in order for consumers to determine what kind of advertisement they are watching.

For food and beverage advertisement as per Table 2 below, it was found that the copywriter played with the vocabulary and proper name to illustrate the theme. In C3 advertisement for example, for the brand Yakult, the 
copy opens to the child endorser mentioning the word "Shirota" to which means good bacteria. From that instant, consumers would be able to analyse the theme to be a beverage advertisement that contains good bacteria. It is then further elaborated in the next sentence spoken by the Mother endorser saying "Contains 30 millions good bacteria Shirota strain for your guts. More than 80 years of experience. Yakult for everyone everyday". From the explanation in the copy said by the Mother, consumers' assumption of the theme as a beverage advertisement is further strengthened by the details of the second sentence on how the Yakult beverage contains 30 million good bacteria that is good for them.

Table 2. Theme

\begin{tabular}{l} 
C3 Product: Yakult \\
Celebrity Endorser: Scha Alyahya and Awal Ashaari \\
Copy: \\
Lara: Shirota \\
Scha: Contains 30 millions good bacteria Shirota strain for your guts. More than 80 years of experience. \\
Yakult for everyone everyday. \\
Yakult \\
\hline C4 \\
Product: Burger King \\
Celebrity Endorser: Daler Yusuff \\
Copy: Burger King, have it your way!
\end{tabular}

As for $\mathrm{C} 4$ advertisement in Table 2 above, very simple copy and mainly depended on the visuals of the advertisement itself, as the only copy used in the advertisement in a only line where the endorser mentions the proper name which is the product itself, from the copy "Burger King, have it your way!". With the direct use of the product in the only copy in the advertisement, consumers know the theme of the advertisement is food and that you can have the food in the way you like it. From there, consumers are attracted to the simple copy use and can easily register the theme that the advertisement wants to deliver.

\subsection{Lexical}

According to Fairclough (1995), lexical are words that relates to a specific or certain vocabulary of any given language on its own. Fairclough (1995) further zoomed the category into the sub-category, metaphor.

\subsubsection{Metaphor}

Cambridge Dictionary (2018) explains metaphors as expressions that are commonly found in literature to which helps describe an object or person by referring to another thing that is similar in characteristics of that object or person. For this study, metaphors are often used in advertisements to create the suspense towards the consumers.

Table 3. Metaphor

\section{C5 Product: Oppo F5}

Celebrity Endorser: Fattah Amin and Ayda Jebat

Copy:

Fattah: Lock out all the noise

Ayda: Uncertain of my choice. That's my way.

Fattah: True self shines through

Ayda: A new found a way to it.

Fattah: Just like, to capture the real you. There can only be 1 way. Oppo F5, capture the real you. Oppo, selfie expert and leader.

\section{C6 Product: Naffos}

Celebrity Endorser: Fazura

Copy: I am the one and only. I am Fazura, and the only phone as beautiful as me. Action ready. 0.2 seconds perfection immediately. The new Neffos X1 and X1 Max 
Metaphor approach for electronics advertisements for Table 3 below uses other words rather than the product name itself. For example, in C5, the copy at the beginning keeps consumers guessing what the two celebrity endorsers is referring to as they were describing the characteristics of the product by using metaphor like "lock out all the noise" and "true self shines through". Metaphorically, the endorser is referring to the product that they are advertising, but in order to capture consumer's attention, the copy used is to get consumers guessing on what the endorser is meaning. With this, the advertisement copy explains that they mean on the last copy "Just like, to capture the real you. There can only be 1 way. Oppo F5, capture the real you. Oppo, selfie expert and leader." By this, the endorsers would like to capture the consumers' attention to the fact that the main feature of the product is its self-built camera to make consumers the selfie experts.

Contrary to C5, advertisement C6 in Table 3 above uses metaphor differently where the celebrity detailed the phone as beautiful in "... the only phone as beautiful as me". Consumers who appreciate and likes how the endorser looks will relate well to the advertisement. Indefinitely consumers who want pretty looking phone and a phone that good enough to be used by the endorser will be attracted to the advertisement.

\subsection{Cohesion}

Cohesion as mentioned by Fairclough (1995) is when a word is used for continuity of a sentence. Fairclough (1995) further divided the category into repetition and conjunction.

\subsubsection{Repetition}

If interventions were studied, detail all important adverse events (events with serious consequences) and/or side effects in each intervention group.

Literary Devices (2018) defines as a literary device where in the text has a repetition of the same words or phrases a few times, to make the text easy to remember.

In this research, it was found that personal, oral and home care advertisement plays a subtle repetition approach where it is mainly the repetition of the brand to increase the awareness and to recall the brand. The presence of advertisement can be seen in C7 in (see Table 4 below) where the product name is repeated three times. The first product name is mentioned in the first sentence of the copy "It's so hot outside, skin will be dark and dry. You don't need to touch like that, use the new body serum from Enchanteur." This is where the problem and solution is introduced. The second product mention is in the second sentence where the copy mentions and reminds the consumer the benefits of the product "Enchanteur body serum all in 1. 1 serum a lot of benefits. SPF24, whitening and 24-hour moisture". Then the advertisement ends with the product name itself, totally to repeat the product name to three times in the advertisement "Enchanteur body serum all in one".

Table 4. Repetition

\section{C7 Product: Enchanteur Paris Serum}

Celebrity Endorser: Nelydia Senrose

Copy: It's so hot outside, skin will be dark and dry. You don't need to touch like that, use the new body serum from Enchanteur.

Enchanteur body serum all in 1. 1 serum a lot of benefits. SPF24, whitening and 24-hour moisture. Fair skin and glowing. Enchanteur body serum all in one.

C8 Product: Johnson and Johnson Milk Bath

Celebrity Endorser: Scha Alyhaya

Copy:

Scha: Lara is still growing. Her skin is still thin and needs love. So I don't use family bodywash that dries her skin. I only use Johnson's milk that gives two times the moisture and two times the nutrients. To protect and maintain her skin. Maintain soft and clean. So she's free to explore all day. Johnson's milk. 2 times the moisture, 2 times the nutrients

Same goes to C8 advertisement, where the product name is mentioned twice in the advertisement for good product recognition. The first product name is mentioned in the first half of the copy "Lara is still growing. Her skin is still thin and needs love. So I don't use family bodywash that dries her skin. I only use Johnson's milk that gives two times the moisture and two times the nutrients". Whilst the second mention of the product name is in the second half of the advertisement "To protect and maintain her skin. Maintain soft and clean. So she's free 
to explore all day. Johnson's milk. 2 times the moisture, 2 times the nutrients".

The use of product name repetition works well when the objective of all advertisements is so consumers can register the product name, and that using the repetition twice in the advertisement in order to maintain the repeated word together with the product name in order to bring awareness to the consumers, where once is used at the beginning to let consumers know the product name and the second time near the end of the advertisement to remind consumers of the product name before the copy line ends. This way is effective so consumers register the product name twice as compared to other advertisement where the product name is only mentioned at the end of the copy or at the beginning of the copy. For repetition, I can be found in this study that repetition is often used in most advertisement to increase the brand awareness and brand recall. Repetition angles used in the advertisement in this study are product name repetition or a repetition of describing the product, to which both can grab the consumers attention.

\subsubsection{Conjunction}

Conjunction by Merriam-Webster (2018) is that it is a form of sentence that uses conjunction to form together sentences, clauses, phrases or words. Common conjunctions known are and, but and although.

Cosmetic advertisements in Table 5 below of playful use of conjunction makes the advertisement sound more appealing. C9 advertisement in the first sentence of the copy "How to be beautiful like you?" conjunction can be seen in the first word itself "How" where it depicts a certain manner of a conjunction at the beginning of the sentence rather than having a conjunction in the middle of a sentence to combine to meanings in one. Another conjunction can be seen when the endorser talks and mentions that "Easy, just roll.. Eh wait not like that. Chriszen roller moist cream just press and roll until your pretty". The word "until" is a conjunction for time to illustrate until when you would need to use the product and achieve what it is you want when you purchase the product.

Table 5. Conjunction

C9 Product: Chriszen
Celebrity Endorser: Nelydia Sebrose
Copy:
Girl: How to be beautiful like you?
Nelydia: Easy, just roll.. Eh wait not like that. Chriszen roller moist cream just press and roll until your
pretty.
Chriszen
Product: Garnier Light
Celebrity Endorser: Lisa Surihani
Copy: We like Garnier light, look at it. Until 2 tones more fairer in just 2 weeks and much more. Black
spots also decreased. Pores also reduced. Skin definitely fairer. It's fresh naturally. That is why 9/10
Malaysian woman likes it. Garnier light, who else loves us.
$\quad$

C10 advertisement above on the other hand differed from C9 where in table 5 above it showed the first use of conjunction can be seen in the second sentence where the copy states that "Until 2 tones more fairer in just 2 weeks and much more". The word "until" is conjunction used just like C9 advertisement, however for C10, it's more of explaining that because of the products, her skin tone has increase lighter by 2 tones, while the other conjunction of the word "and" is just the basic of use of conjunction to join "Until 2 tones more fairer in just 2 weeks" sentence with "much more" rather than having to separate it. Without the use of conjunction, the copy in advertisement will become longer and will tend to bore consumers out, while if short and simple copy yet still meeting the objectives on what the product wants to tell consumers, then consumers would understand the product more.

\section{Discussion}

This study shows that the elements of critical discourse in copywriting on Malaysian celebrity television advertisement. The discourse in copywriting is based on Fairclough (1995) critical discourse analysis theory highlighting on the first dimension out of three dimensions mentioned by Fairclough (1995). However, the findings analyzed in this study clearly supports Fairclough (1995) critical discourse theory on textual analysis 
aspect where the sub-categories are grammar, lexical and cohesion. The objectives of the research is to identify and discuss the elements of critical discourse in copywriting on Malaysian celebrity television advertisement video. This study will focus on the textual analysis, one of the three dimensions of Fairclough's (1995) critical discourse analysis.

The results for the objective have revealed that all the television advertisement used to analyse objective have the presence of Fairclough's (1995) first dimension of textual analysis of the critical discourse theory. In each of the advertisement used to identify the elements of discourse in copywriting on Malaysian celebrity television advertisement, the first dimension of Fairclough (1995) critical discourse can be identified in all of the advertisement used. However, not all advertisements succumb to each sub-category under the textual analysis. This means that a certain advertisement has the presence of grammar and metaphor, but does not have repetition and conjunction.

This study implicates the copywriter, product owner and consumers that are directly and indirectly involved in Malaysian television advertisements. The results of the study implicate copywriter in terms of writing better and more futuristic copies. The copywriter needs to ensure that the copy used in the future will benefit both the brand and consumers. The copy in the advertisement should be simple and easy to understand, so the key message is delivered immediately to the consumers. With this, the improvement of the copy in the advertisement can help deliver better copy in the future. Other than that, the results of this study also implicate the product owner where the product owner needs to be more involved in the copywriting process to make sure that the message the product owner wants to deliver to the consumer is delivered well through the advertisement. For example, when the copywriter gives the first draft of copy to the product owners, they must first make sure that the copy can be easily understood by consumers as well as make sure the key message is within the copy given.

Other than that, product owners need to make sure that all the copy in the text given by the copywriter is legally approve by their internal legal team as well as make sure that the copy will be approved by the censorship committee. Lastly, the results of the study implicate the consumers itself in terms of understanding why the advertisement uses such copy, to capture the consumer's attention. Other than that, consumers should know why the advertisement uses simple and influencing copy to influence consumers to buy the product. Consumers should also be open to giving feedback to the product owners based on the advertisement they see, so the product owners can understand more about their consumers. In addition, consumers will feel that what they say plays a role in their favorite brand. With this, copywriting in television advertisement helps copywriting, product owner and consumers understand more about the content.

Further studies should be done towards copywriting in television advertisement. This study hopes to benefit many parties to know more about the importance of copy in advertisement and how it plays a big role in influencing consumers, increasing purchase decisions for the product owners as well as getting the copywriter know what is the best context used in advertisement.

\section{Acknowledgments}

This research is sponsored under Universiti Putra Malaysia Graduate Grant GP-IPS/2018/9590900.

\section{References}

Advertising Yearbook 2011. (2012). Korean advertising agencies. Seoul, South Korea: Cheil Worldwide.

Bartsch, C. (1997). Oral style, written style, and Bible translation. Notes on Translation, 11, 41-48.

Basil, D. Z., \& Herr, P. M. (2006). Attitudinal balance and cause-related marketing: An empirical application of balance theory. Journal of Consumer Psychology, 16(4), 391-403. https://doi.org/10.1207/s15327663jcp1604_10

Bergkvist, L., Hjalmarson, H., \& Magi, A. W. (2016). A new model of how celebrity endorsements work: Attitude toward the endorsement as a mediator of celebrity source and endorsement effects. International Journal of Advertising: The Review of.

Biber, D., \& Gray, B. (2013). Discourse Characteristics of Writing and Speaking Task Types on the TOEFL IBT Test: A Lexico-Grammatical Analysis. ETS Research Report Series. i-128 https://doi.org/10.1002/j.2333-8504.2013.tb02311.

Brown, G., \& Yule, G. (1983). Discourse Analysis. Cambridge: Cambridge University Press. https://doi.org/10.1017/CBO9780511805226

Chafe, W. (1992). Discourse: An overview. In W. Bright et al. (Eds.), International encyclopedia of linguistics. Oxford: Oxford University Press. 
Chilton, P., Tian, H., \& Wodak, R. (2010). Reflections on discourse and critique in China and the West. Journal of Language and Politics, 9(4), 489-508. https://doi.org/10.1075/jlp.9.4.02chi

Choi, S. M., Lee, W., \& Kim, H. J. (2005). Lessons from the rich and famous: A cross-cultural comparison of celebrity endorsement in advertising. Journal of Advertising, 34, 85-98. https://doi.org/10.1080/00913367.2005.10639190

Conjunction. (2018). In Merriam-Webster.com. Retrieved June 15, 2018, from https://www.merriam-webster.com/dictionary/conjunction

Constanzo, P. J., \& Goodnight, J. E. (2008). Celebrity endorsement: Matching Celebrity and Endorsed Brand in Magazine Advertisement. Journal of Promotion Management, 49-62.

Coulthard, M. (1994). Advances in Written Text Analysis (pp. 1-11). London: Routledge.

Economic Times. (2017). Definition of “Advertising”. Retrieved July 16, 2017, http://economictimes.indiatimes.com/definition/advertising

Edwards, S., \& La Ferle, C. (2009). Does gender impact the perception of negative information related to celebrity endorsers? Journal of Promotion Management, 15(1), 22-35. https://doi.org/10.1080/10496490902837940

Fairclough, N. (1989). Language and Power. London: Longman.

Fairclough, N. (1992). Discourse and Social Change. Cambridge: Polity Press.

Fairclough, N. (1995). Critical Discourse Analysis. London: Longman.

Fleck, N., Korchia, M., \& Le Roy, I. (2012). Celebrities in advertising: Looking for congruence or likability? Psychology \& Marketing, 29(9), 651-662. https://doi.org/10.1002/mar.20551

Fulcher, R. (2010). Critical Discourse Analysis. London and New York: Longman.

Gee. J. P., \& Handford, M. (Eds.). (2013). The Routledge Handbook of Discourse Analysis.

Halliday, M. A. K., \& Hasan, R. (1976). Cohesion in English. London: Longman.

Halonen-Knight, E., \& Hurmerinta, L. (2010). Who endorses whom? Meanings transfer in celebrity endorsement. Journal of Product \& Brand Management, 19(6), 452-460. https://doi.org/10.1108/10610421011085767

Hoey, M. (1994). Signalling in Discourse: A Functional Analysis of a Common Discourse Pattern in Written and Spoken English. Chap. 3 of Coulthard, M. (1994). Advances in Written Text Analysis. London: Routledge.

Johnstone, B. (2007). Discourse Analysis (2nd ed.). Oxford: Blackwell.

Karimova, G. Z. (2011). Interactivity and advertising communication. Journal of Media and Communication Studies, 3(5), 160-169.

Kim, J. (2007). Observe advertising effectiveness correctly and create ads right. Ad Information, 321, 88-93.

McCarthy, M. (1993). Discourse Analysis for Language Teachers. Cambridge University Press.

McCutcheon, L. E., Ashe, D. D., Houran, J., \& Maltby, J. (2003). A Cognitive Profile of Individuals Who Tend to Worship Celebrities. Journal of Psychology, 137(4), 309-332. https://doi.org/10.1080/00223980309600616

Metaphor. (2018). In dictionary.cambridge.org. Retrieved July 15, 2018, from https://dictionary.cambridge.org/dictionary/english/metaphor

Paltridge, B. (2006). Discourse analysis: an introduction. London: Continuum Discourse Series.

Petri, S. (2012). The lost art of creative copywriting in advertising. Retrieved from February 16, 2017 , https://www.theguardian.com/media-network/media-network-blog/2012/dec/04/lost-art-creative-copywritin g-advertising

Rahim, N. A., Affendi, N. R. N. M., \& Pawi, A. A. A. (2017). Dissemination of Values and Culture through the E-Folklore. The Turkish Online Journal of Educational Technology, 16(1), 32-36.

Repetition. (2018). In literarydevices.net. Retrieved July 16, 2018, from https://literarydevices.net/repetition/

Schiffrin, D. (1994). Approaches to Discourse. Cambridge: Blackwell.

Stubbs, M. (1983). Discourse Analysis the Sociolinguistic Analysis of Natural Language. Chicago, IL The University of Chicago Press. 
Todirascu, A., Franc, T., Nuria Gala, Fairon, C., Ligozat, A., \& Bernhard, D. (2013). Coherence and Cohesion for the Assessment of Text Readability. In The 10th International Workshop on Natural Language Processing and Cognitive Science (pp. 11-19). Marseille, France.

Um, N. H., \& Lee, W. N. (2015). Korean Advertising Practitioners' Perspectives on Celebrity Endorsement. Journal of Promotion Management, 21(1), 33-54. https://doi.org/10.1080/10496491.2014.946210

Van Dijk, T. A. (2008). Discourse and Context: A Socio-cognitive Approach. Cambridge: Cambridge University Press. https://doi.org/10.1017/CBO9780511481499

Winter, E. (1994). Clause Relations as Information Structure: Two Basic Text Structures in English. Chapt. 4 of Coulthard, M. (1994). Advances in Written Text Analysis. London: Routledge.

\section{Copyrights}

Copyright for this article is retained by the author(s), with first publication rights granted to the journal.

This is an open-access article distributed under the terms and conditions of the Creative Commons Attribution license (http://creativecommons.org/licenses/by/4.0/). 